\title{
Estrogen enhanced cell-cell signalling in breast cancer cells exposed to targeted irradiation Chunlin Shao ${ }^{1}$, Melvyn Folkard ${ }^{2}$, Kathryn D Held ${ }^{3}$ and Kevin M Prise*4
}

\begin{abstract}
Address: ${ }^{1}$ Institute of Radiation Medicine, Fudan University, No.2094 Xie-Tu Road, Shanghai 200032, PR China, ${ }^{2}$ Gray Cancer Institute, PO Box 100, Mount Vernon Hospital, Northwood, Middlesex, HA6 2JR, UK, ${ }^{3}$ Dept Radiation Oncology, Cox 302, Massachusetts General Hospital, Harvard Medical School, 100 Fruit Street, Boston, MA 02114, USA and ${ }^{4}$ Centre for Cancer Research and Cell Biology, Queen's University Belfast, 97 Lisburn Road, Belfast, BT9 7AB, UK
\end{abstract}

Email: Chunlin Shao - clshao@shmu.edu.cn; Melvyn Folkard - folkard@gci.ac.uk; Kathryn D Held - kheld@partners.org; Kevin M Prise* - k.prise@qub.ac.uk

* Corresponding author

Published: 30 June 2008

BMC Cancer 2008, 8:184 doi:10.1186/147|-2407-8-184
Received: 4 January 2008

Accepted: 30 June 2008

This article is available from: http://www.biomedcentral.com/I47/-2407/8//84

(C) 2008 Shao et al; licensee BioMed Central Ltd.

This is an Open Access article distributed under the terms of the Creative Commons Attribution License (http://creativecommons.org/licenses/by/2.0), which permits unrestricted use, distribution, and reproduction in any medium, provided the original work is properly cited.

\begin{abstract}
Background: Radiation-induced bystander responses, where cells respond to their neighbours being irradiated are being extensively studied. Although evidence shows that bystander responses can be induced in many types of cells, it is not known whether there is a radiation-induced bystander effect in breast cancer cells, where the radiosensitivity may be dependent on the role of the cellular estrogen receptor (ER). This study investigated radiation-induced bystander responses in estrogen receptor-positive MCF-7 and estrogen receptor-negative MDA-MB-23I breast cancer cells.
\end{abstract}

Methods: The influence of estrogen and anti-estrogen treatments on the bystander response was determined by individually irradiating a fraction of cells within the population with a precise number of helium-3 using a charged particle microbeam. Damage was scored as chromosomal damage measured as micronucleus formation.

Results: A bystander response measured as increased yield of micronucleated cells was triggered in both MCF-7 and MDA-MB-23 I cells. The contribution of the bystander response to total cell damage in MCF-7 cells was higher than that in MDA-MB-23I cells although the radiosensitivity of MDA-MB-23I was higher than MCF-7. Treatment of cells with 17 $\beta$-estradiol (E2) increased the radiosensitivity and the bystander response in MCF-7 cells, and the effect was diminished by antiestrogen tamoxifen (TAM). E2 also increased the level of intracellular reactive oxygen species (ROS) in MCF-7 cells in the absence of radiation. In contrast, E2 and TAM had no influence on the bystander response and ROS levels in MDA-MB-23 I cells. Moreover, the treatment of MCF-7 cells with antioxidants eliminated both the E2-induced ROS increase and E2-enhanced bystander response triggered by the microbeam irradiation, which indicates that ROS are involved in the E2enhanced bystander micronuclei formation after microbeam irradiation.

Conclusion: The observation of bystander responses in breast tumour cells may offer new potential targets for radiation-based therapies in the treatment of breast cancer. 


\section{Background}

The radiation-induced bystander effect is the appearance of a biological response in nonirradiated cells neighbouring irradiated cells [1]. The response has been demonstrated in cultured cells and tissues by using different irradiation approaches including low fluences of $\alpha$-particles $[2,3], \gamma$-rays $[4,5]$, heavy ions $[6,7]$, and targeted microbeams which allow cells to be individually irradiated through either the nucleus or cytoplasm [8-10]. Many endpoints have been reported for the bystander responses, including DNA damage markers $[11,12]$ cell death [13], increases in sister chromatid exchanges $[14,15]$, micronuclei $[11,16,17]$, mutations $[18,19]$ genomic instability $[20,21]$, malignant transformation $[22,23]$ and gene expression [24].

Recently, we have found that irradiation through the cytoplasm of a cell has a similar probability of triggering a bystander response to that when the nucleus is directly irradiated $[10,25]$. However, the mechanisms underpinning the bystander effect are still unclear, although cell-tocell communication [26-28] and several signaling factors such as cytokines [29], reactive oxygen species (ROS) $[30,31]$ and nitric oxide (NO) $[32,33]$ have been identified as playing roles. These findings may be of particular importance for exposures at environmentally relevant low doses where cells at risk are traversed by only single tracks of radiation at any one time [34]. Bystander responses may also be relevant to the therapeutic use of radiation because a mechanistic understanding of the effects may lead to approaches to enhance bystander responses in tumours and also possibly to protect surrounding normal tissues.

Although evidence shows that bystander responses can be induced in many types of cells, it is not known whether there is a radiation-induced bystander effect in breast cancer cells, where the radiosensitivity may be dependent on the role of the cellular estrogen receptor (ER)[35]. Estrogens and anti-estrogens are important components of breast cancer development and treatment. The experimental data are contradictory as to whether estrogens and antiestrogens alter the radiation response of breast cancer cells. It has been reported that $17 \beta$-estradiol (E2) prevents radiation-induced apoptosis of ER-positive MCF-7 breast cancer cells, probably mediated through the plasma membrane ER [36]. However, a number of studies have indicated that estradiol treatment increases the radiosensitivity of MCF-7 cells [37-39]. Conversely, treatment with the anti-estrogen, tamoxifen reduces or does not alter the radiosensitivity of MCF-7 cells $[37,40]$, although it has no effect on radiosensitivity of ER-negative MDA-MB-231 breast cancer cells [41]. However, none of these studies have considered the response of breast cells and their modulation by estradiols and anti-estradiols after low dose radiation exposure.

In the present work, we used a charged particle microbeam to deliver exact numbers of helium ions through the nuclei of restricted numbers of MCF-7 and MDA-MB-231 breast cancer cells. We found that radiation-induced bystander responses were generated in both cell lines and that treatment with E2 and/or tamoxifen influenced the bystander response through a ROS-mediated pathway in only MCF-7 cells but not in MDA-MB231 cells.

\section{Methods}

\section{Cell culture and treatments}

ER-positive MCF-7 and ER-negative MDA-MB-231 breast cancer cells (obtained from Cancer Research UK) were cultured in DMEM medium supplemented with $10 \%(\mathrm{v} /$ v) foetal calf serum (FCS), 2 mM L-glutamine, 100 units/ $\mathrm{ml}$ penicillin, and $100 \mu \mathrm{g} / \mathrm{ml}$ of streptomycin. Cells were grown in a humidified atmosphere with $5 \% \mathrm{CO}_{2}$ in air at $37^{\circ} \mathrm{C}$. One day prior to microbeam irradiation, plateau phase cells were seeded at a low density in a $\phi 5 \mathrm{~mm}$ central area of the specially designed microbeam dish consisting of a $3 \mu \mathrm{m}$ thick Mylar film base [42]. The region prepared for cell seeding had been pre-treated with $1.7 \mu \mathrm{g} /$ $\mathrm{cm}^{2}$ Cell-Tak adhesive (Collaborative Biomedical Products, Bedford, MA, USA). One hour after cell seeding, $2 \mathrm{ml}$ of medium was added into the microbeam dish. In some experiments, cells were treated $24 \mathrm{~h}$ before and after microbeam irradiation with $10 \mathrm{nM} 17-\beta$ estradiol (E2), 50 $\mathrm{nM}$ tamoxifen (TAM), $150 \mathrm{U} / \mathrm{ml}$ of the antioxidants superoxide dismutase (SOD) and catalase (CAT), or the combination of E2 with either TAM or antioxidants (all from Sigma, Poole, Dorset, UK). The concentration of E2 utilized for this study was within the range of physiological concentrations which could saturate the ER. TAM with a concentration of 5-fold excess was used to displace E2 from its receptor. These concentrations were also widely applied in other studies $[37,43]$.

\section{Microbeam irradiation}

The Gray Cancer Institute microbeam system was used for this study and details of the experimental set-up have been described elsewhere $[42,44]$. To enable individual nuclei to be identified by the microbeam imaging system, the fully-attached cells were stained with $0.2 \mu \mathrm{g} / \mathrm{ml}$ Hoechst 33342 for $1 \mathrm{hr}$ prior to irradiation. Excess stain was removed by washing the cells with serum free medium containing $10 \mathrm{mM}$ HEPES before irradiation, and cells were maintained in this medium during microbeam irradiation. Typically, $1200 \pm 50$ (mean \pm SE) individual cells in total were scanned in the microbeam dish just before irradiation. A fraction of cells, from $1 \%$ to $100 \%$ of the cells in the population, were individually 
irradiated through the center of the nucleus with a precise number of helium-3 ions $\left({ }^{3} \mathrm{He}^{2+}\right)$ with an LET of $100 \mathrm{keV} /$ $\mu \mathrm{m}$. Using these ions, $99 \%$ of cell nuclei could be precisely targeted with an accuracy of $\pm 2 \mu \mathrm{m}$. Immediately after irradiation, the culture medium was replaced with 2 $\mathrm{ml}$ of complete medium with or without drugs and incubation continued until treatment for micronucleus analysis.

\section{Micronucleus assay}

The cytokinesis block technique was used to assay for micronuclei (MN) in situ. $24 \mathrm{~h}$ after irradiation, the culture medium in the microbeam dishes was replaced with medium containing $1 \mu \mathrm{g} / \mathrm{ml}$ cytochalasin-B. The cells were incubated for a further $48 \mathrm{~h}$ then fixed with methanol: acetic acid $(9: 1(\mathrm{v} / \mathrm{v}))$ for $20 \mathrm{~min}$. After air-drying, cells were stained with $10 \mu \mathrm{g} / \mathrm{ml}$ acridine orange plus 10 $\mu \mathrm{g} / \mathrm{ml}$ Hoechst 33342 for $5 \mathrm{~min}$. This Hoechst treatment enhanced visualisation of both nucleus and micronucleus. MN were scored in binucleated (BN) cells and classified according to the criteria of [45]. The $\mathrm{MN}$ yield, $\mathrm{Y}_{\mathrm{MN}}$ was calculated as the ratio of the number of $\mathrm{MN}$ to the number of scored BN cells.

\section{ROS assay}

To investigate the possible role of ROS in the E2-induced effect, $2 \times 10^{5}$ MCF-7 or MDA-MB-231 cells were treated with $10 \mathrm{nM}$ E2 or E2 plus $150 \mathrm{U} / \mathrm{ml}$ SOD and CAT for 24 $\mathrm{h}$. Then, the intracellular ROS level in the cells was measured in situ by using 5', 6'-chloromethyl-2', 7'-dichlorodihydro-fluorescein diacetate $\left(\mathrm{CM}-\mathrm{H}_{2} \mathrm{DCFDA}\right.$, Molecular Probes Inc.). Briefly, cells were treated with $3.5 \mu \mathrm{M}$ CM$\mathrm{H}_{2}$ DCFDA for $20 \mathrm{~min}$ at $37^{\circ} \mathrm{C}$ and then washed with FCS free medium for $15 \mathrm{~min}$. The fluorescence images of at least 100 randomly selected cells per dish were captured using a 3 CCD cooled colour camera (Photonic Science Ltd, East Sussex, UK) attached to a fluorescence microscope (Zeiss Axioskop). The exposure conditions were standardised to allow quantitative comparisons of the relative fluorescence intensity of the cells between groups.

\section{Statistical analysis}

Statistical analysis was done on the means of the data obtained from at least three independent experiments. Two replicates were counted for each experimental point in each experiment to determine the micronucleus yield. All results are presented as means \pm SE. Significance was assessed using the Student's t-test at $P<0.05$.

\section{Results}

\section{Radiation induced bystander effect}

When a fraction of either MCF-7 or MDA-MB-231 cells within a population were individually targeted through their nuclei with a precise number of helium particles, $\mathrm{MN}$ were induced. The yields of $\mathrm{MN}$ in the targeted popu- lations increased non-linearly with the fraction of irradiated cells (Fig. 1). When $100 \%$ of cells were irradiated with 1 or $5{ }^{3} \mathrm{He}^{2+}$ particles, the yield of radiation-induced MN in the MDA-MB-231 cells was higher than that in the MCF-7 cells, indicating that the MDA-MB-231 cells have a higher radiosensitivity than MCF-7 cells. In contrast, it was calculated from the data in Fig. 1 that, when 12 cells ( $1 \%$ of the population) were individually targeted with 1 $\mathrm{He}^{2+}$ particle, although not every targeted cell leads to the production of a $\mathrm{MN}, \mathrm{MN}$ were still observed in an additional 33 MCF-7 cells or 29 MDA-MB-231 above background which provides clear evidence that $\mathrm{MN}$ are produced in non-targeted bystander cells at a similar level in both cell lines.
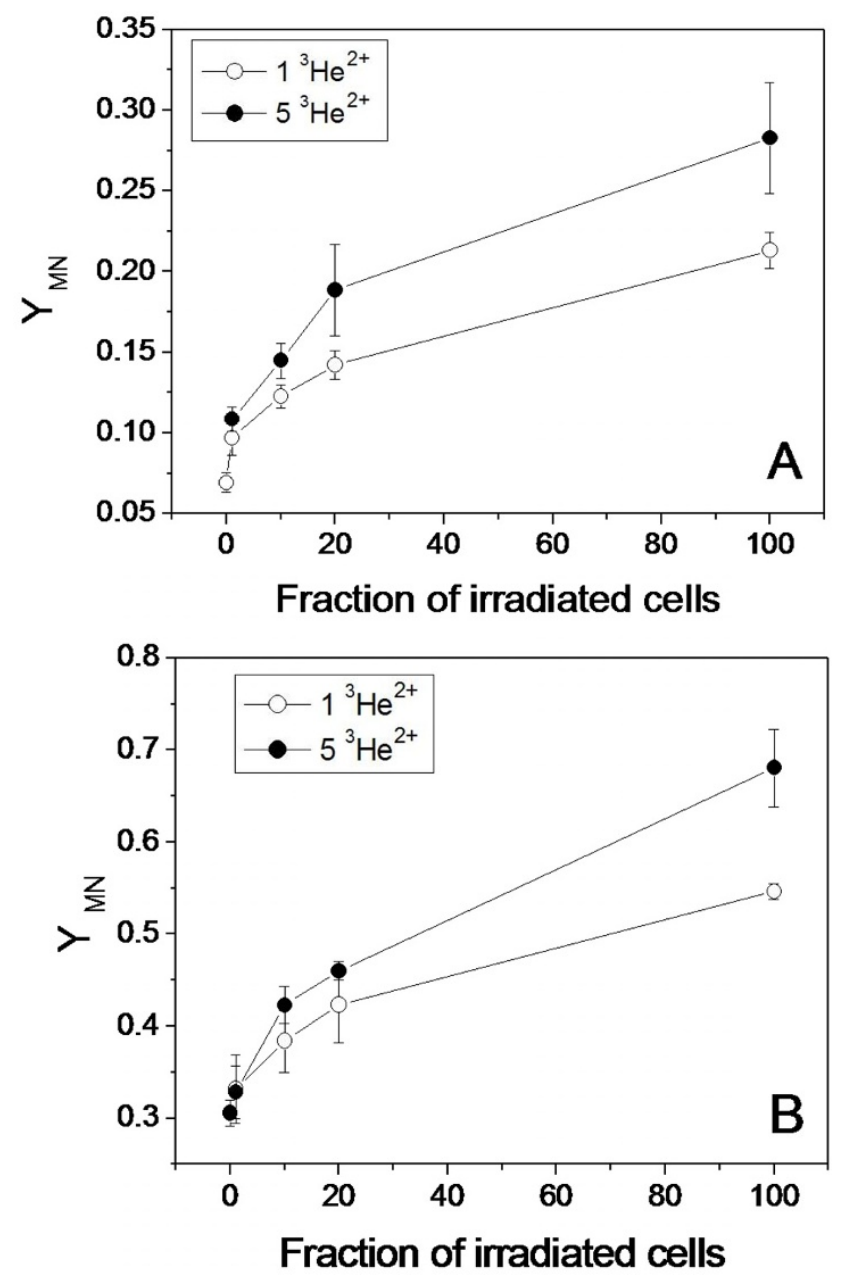

Figure I

Radiation-induced $\mathrm{MN}$ formation in breast cancer cells. Different fractions of cells within the populations of MCF-7 (A) and MDA-MB-23 I (B) were individually irradiated with $\mathrm{I}$ or $5{ }^{3} \mathrm{He}^{2+}$ particles, respectively. 
If no bystander effect occurred in the population where $100 \%$ of cells were targeted individually, the yields of $\mathrm{MN}$ when only a fraction of the cells were irradiated can be mathematically predicted. This uses the MN yield when $100 \%$ of cells were irradiated by the method described previously [32] and the yields are listed in Table 1. In comparison to the data in Fig. 1, the predicted MN yields are smaller than the measured values for both the MCF-7 and MDA-MB-231 cell lines. The difference in yield of MN between the measured value and the predicted value is defined as the yield of bystander MN (see Table 1). In general, the bystander MN yield increased with the fraction of irradiated cells and with the radiation dose (number of particles delivered to the targeted cells). In addition, although the bystander MN yield in MBA-MD-231 cells was higher than that of MCF-7 cells, the bystander MN as a percentage of the total MN in the MDA-MB-231 population was less than that of MCF-7 cells. For example, when 1 to $20 \%$ of cells in a population are irradiated with 1 or $5{ }^{3} \mathrm{He}^{2+}$ particles, the bystander $\mathrm{MN}$ as a percentage of the total MN ranges from $5.8 \%$ to $18.9 \%$ for the MDA-MB231 cells, and from $27.1 \%$ to $40.1 \%$ for the MCF-7 cells. Therefore, MCF- 7 cells are more effective in generating a bystander response than MDA-MB-231 cells, which is in contrast to the differences in radiosensitivity between the two cell lines.

\section{Influence of E2 and TAM on the bystander response}

E2 is an important factor involved in breast cancer development. To investigate whether $\mathrm{E} 2$ can influence the radiation-induced bystander effect, we treated cells with E2 for $24 \mathrm{~h}$ before irradiation and afterwards until assayed for $\mathrm{MN}$. Results are illustrated in Fig. 2 where a fraction of either MCF-7 or MDA-MB-231 cells were individually irradiated with $5{ }^{3} \mathrm{He}^{2+}$ particles. The E2 treatment itself significantly increased the MN background in MCF-7 cells ( $P$ $<0.05$ ) but not in MDA-MB-231 cells, which is in agreement with a previous report that E2 increases the formation of MN in ER-positive MCF-7 cells [46]. When 100\% of the cells were irradiated, E2 also increased the production of MN in MCF-7 cells and this increase is larger than the E2-enhanced MN background (Fig. 2A). However, E2 had no influence on MDA-MB-231 cells (Fig. 2B). Therefore, E2 increases the radiosensitivity of MCF-7 cells but not MDA-MB-231 cells.

Interestingly, the $\mathrm{MN}$ yield was also increased by $\mathrm{E} 2$ treatment when $1 \%$ or $10 \%$ of cells in the MCF-7 population were irradiated. According to the MN yield when $100 \%$ of cells were irradiated in the presence of E2, the predicted yield of $\mathrm{MN}$, assuming no bystander effect occurred in the fraction-irradiated population, and the yield of bystander $\mathrm{MN}$ in the E2-treated MCF-7 cells were calculated and are listed in Table 2.

Comparing the data in table 2 with those in table 1 , it is seen that treatment of MCF-7 cells with E2 increased the yield of bystander $\mathrm{MN}$ when $1 \%$ or $10 \%$ of the cells were individually irradiated with 1 or $5{ }^{3} \mathrm{He}^{2+}$ particles. For example, when $1 \%$ of cells were irradiated with $1{ }^{3} \mathrm{He}^{2+}$ particle, E2 increased the bystander MN yield from 0.0262 to 0.0347 . This E2-enhanced bystander response could result from the E2-enhanced radiosensitivity of MCF-7 cells.

Figure 2 also illustrates that when the cells were treated with TAM to compete for ER with E2, both radiosensitivity and the radiation-induced bystander effect on MCF-7 cells were diminished to the levels in the absence of E2 treatment. In addition, treatment of cells with TAM plus E2 did not show any influence on radiation damage to MDA-MB231 cells. Treatment with TAM alone had no influence on the radiosensitivity of either cell line (data not shown).

\section{ROS contributes to the E2-enhanced radiation effect in MCF-7 cells}

To investigate the signaling factors involved in the E2enhanced cellular damage in MCF-7 cells, we measured the levels of intracellular ROS in cells with or without E2 treatment. Fig. 3 illustrates that, when MCF-7 cells were treated with $10 \mathrm{nM} \mathrm{E} 2$ for $24 \mathrm{~h}$, the levels of ROS increased 1.17 fold relative to controls. When SOD and CAT were present during E2 treatment, the level of ROS in MCF-7 cells was decreased to $93 \%$ of the control. In the

Table I: The predicted yield of MN and the measured yield of bystander MN.

\begin{tabular}{|c|c|c|c|c|c|c|c|c|}
\hline \multirow[b]{3}{*}{ Fraction of irradiated cells } & \multicolumn{4}{|c|}{ MCF-7 cells } & \multicolumn{4}{|c|}{ MDA-MB-23I cells } \\
\hline & \multicolumn{2}{|c|}{ Predicted $Y_{M N}$} & \multicolumn{2}{|c|}{ Bystander $Y_{M N}$} & \multicolumn{2}{|c|}{ Predicted $\mathrm{Y}_{\mathrm{MN}}$} & \multicolumn{2}{|c|}{ Bystander $Y_{M N}$} \\
\hline & ${ }^{3} \mathrm{He}^{2+}$ & $5{ }^{3} \mathrm{He}^{2+}$ & ${ }^{3} \mathrm{He}^{2+}$ & $5{ }^{3} \mathrm{He}^{2+}$ & ${ }^{3} \mathrm{He}^{2+}$ & $5{ }^{3} \mathrm{He}^{2+}$ & ${ }^{3} \mathrm{He}^{2+}$ & $5{ }^{3} \mathrm{He}^{2+}$ \\
\hline $1 \%$ & 0.071 & 0.071 & $0.026(27.1 \%)$ & $0.037(34.3 \%)$ & 0.308 & 0.309 & $0.024(7.2 \%)$ & $0.019(5.8 \%)$ \\
\hline $10 \%$ & 0.084 & 0.091 & 0.039 (31.9\%) & $0.054(37.5 \%)$ & 0.330 & 0.343 & $0.054(14.0 \%)$ & $0.080(\mid 8.9 \%)$ \\
\hline $20 \%$ & 0.098 & 0.11 & $0.044(31.0 \%)$ & 0.077 (40.1\%) & 0.354 & 0.380 & $0.069(16.4 \%)$ & $0.080(17.4 \%)$ \\
\hline
\end{tabular}

A fraction of cells within the MCF-7 and MDA-MB-23I populations were individually irradiated with a precise number of ${ }^{3} \mathrm{He}^{2+}$ particles. Data in parentheses are the bystander $M N$ as a percentage of total $M N$. 

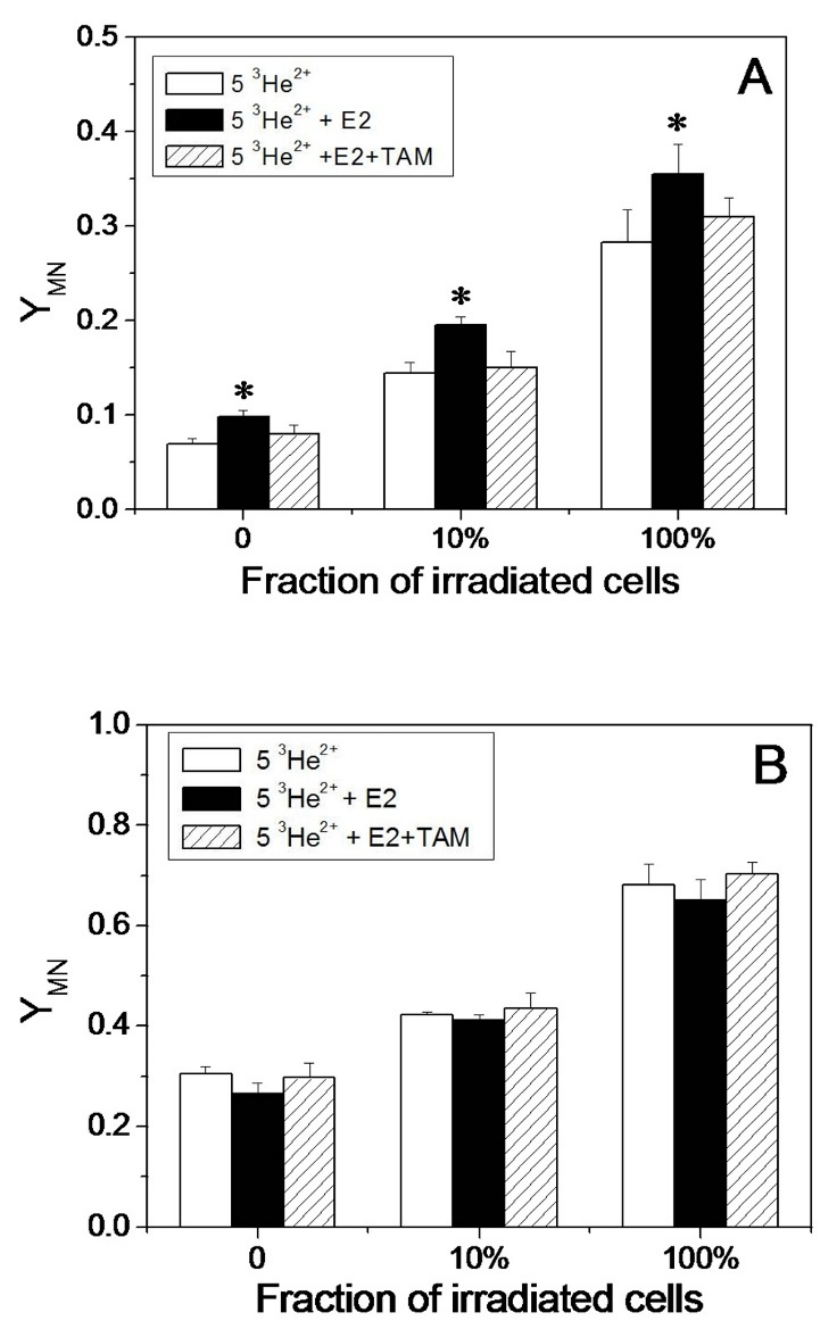

Figure 2

Influence of E2 and TAM on radiation-induced $M N$ formation. A fraction of MCF-7 (A) or MDA-MB-23 I (B) cells were individually irradiated with $5{ }^{3} \mathrm{He}^{2+}$ particles without or with pre-treatment with E2 or E2+TAM $\left(^{*}, P<0.05\right.$ compared to the $\mathrm{MN}$ yield without E2 treatment).

ER-negative MDA-MB-231 cells, E2 treatment had no influence on the levels of ROS although treatment with antioxidants decreased the intracellular levels of ROS (not significant).

To investigate whether the E2-induced ROS contributes to the radiation-induced bystander response, we measured the yield of $\mathrm{MN}$ in the fraction-irradiated MCF-7 population treated with SOD and CAT antioxidants in the presence of E2. Results are shown in Fig. 4 where $10 \%$ and $100 \%$ of MCF-7 cells were individually irradiated with 1 ${ }^{3} \mathrm{He}^{2+}$ particle. The antioxidant treatment eliminated the E2-enhanced MN background, which corresponds to the result in Fig. 3 and hence confirms that ROS are the source of E2-induced $\mathrm{MN}$ in MCF-7 cells. Importantly, when $100 \%$ of MCF-7 cells were irradiated, the antioxidant treatment not only diminished E2-enhanced MN formation but reduced the $\mathrm{MN}$ to a very low level, which indicates that ROS contribute to the DNA damage induced by direct radiation. From the measured $\mathrm{MN}$ yields when $100 \%$ of the cells were irradiated with antioxidant treatment, we calculated the predicted $\mathrm{MN}$ yield assuming no bystander effect occurred when $10 \%$ of cells were irradiated and found that this matched the actual $\mathrm{MN}$ yield (Fig. 4). Accordingly, ROS not only contribute to the direct radiation-induced cellular damage but are also involved in the E2-enhanced bystander response of $\mathrm{MN}$ induction in MCF-7 cells.

\section{Discussion}

This study finds that, when a fraction of cells are precisely irradiated with a counted number of ${ }^{3} \mathrm{He}^{2+}$ particles, the bystander response, measured as an increased yield of $\mathrm{MN}$, can be produced in both non-irradiated MCF-7 and MDA-MB-231 cells, independent of ER status. Radiationinduced signalling factors could contribute to these bystander responses. For example, it has been reported that the conditioned medium from irradiated MCF-7 or MDA-MB-231 cells contained twofold more TGF- $\beta 1$ than that from nonirradiated cells [47]. Also significant evidence for the role of paracrine signalling in response to radiation exposure has been reported (See [48]for a review). Our previous studies have shown that TGF- $\beta 1$ is an important $t$ bystander signaling factor which can further raise the level of intracellular ROS and NO and then cause DNA damage $[49,50]$.

Interestingly, the contribution of the bystander response to cellular damage in ER-positive MCF-7 cells was higher than that in ER-negative MDA-MB-231 cells. Moreover, treatment of cells with $\mathrm{E} 2$ increases the radiation-induced bystander damage in the ER-positive MCF-7 cells but not in the ER-negative MDA-MB-231 cells, and this E2enhanced bystander response in MCF-7 cells can be reversed by tamoxifen, an anti-estrogen reagent.

The effects of E2 on breast cancer cells are complicated and sometimes inconsistent. It has been reported that E2 acts as both a growth factor and a survival factor for breast cancer cells and prevents cell death from apoptosis [36]. However, E2 is a carcinogen and can induce multiple forms of DNA damage such as single strand breaks, chromosome aberrations, and gene mutations [51]. We find here that the effect of E2 on DNA damage is dependent on the ER status of the cells. E2 can induce MN in ER-positive MCF-7 cells but not in ER-negative MDA-MB-231 cells, which is in agreement with other studies [46,52]. Fisher et al. suggested that the E2-induced formation of $\mathrm{MN}$ was not due to the chromosome damaging activity of estradiol 
Table 2: The predicted yield of MN and the measured yield of bystander MN in MCF-7 cells.

\begin{tabular}{ccccc}
\hline Fraction of irradiated cells & \multicolumn{2}{c}{ Predicted $Y_{M N}$} & Bystander $Y_{M N}$ \\
\cline { 2 - 5 } & $I^{3} \mathrm{He}^{2+}$ & $5{ }^{3} \mathrm{He}^{2+}$ & $\mathrm{I}^{3} \mathrm{He}^{2+}$ & $5{ }^{3} \mathrm{He}^{2+}$ \\
\hline $1 \%$ & 0.010 & 0.010 & $0.035(25.8 \%)$ & $0.057(36.2 \%)$ \\
$10 \%$ & 0.114 & 0.124 & $0.067(37.1 \%)$ & $0.072(36.7 \%)$ \\
\hline
\end{tabular}

A fraction of cells within the population, which had been treated with E2 for $24 \mathrm{~h}$, were individually irradiated with a precise number of ${ }^{3} \mathrm{He}{ }^{2+}$ particles. Data in parentheses are the bystander $\mathrm{MN}$ as a percentage of total $\mathrm{MN}$.

but to stimulation of MCF-7 proliferation. For our experiment, the cells were seeded on dishes pre-treated with Cell-Tak so that the cell plating efficiency was 100\%; shortly after irradiation, the cell growth was blocked by cytochalasin-B. Under these conditions, we did not find that the cell proliferation was increased by E2. Thus, E2induced $\mathrm{MN}$ in MCF-7 cells reported here could not result from increased cell proliferation but is generated from the cytotoxic effect of E2.

Direct evidence in the present study shows that E2induced responses of ROS and $\mathrm{MN}$ induction are ERdependent. Also, the ROS produced contribute to E2induced DNA damage in MCF-7 cells since this damage was reduced by antioxidants. It has been reported that several types of free radical-mediated DNA damage can be induced by estrogens and their metabolites. For instance, 8-hydroxyguanine, formed by hydroxyl radical reaction with guanine bases, is increased over control values in DNA of cells incubated with estradiol [53]. In fact, the

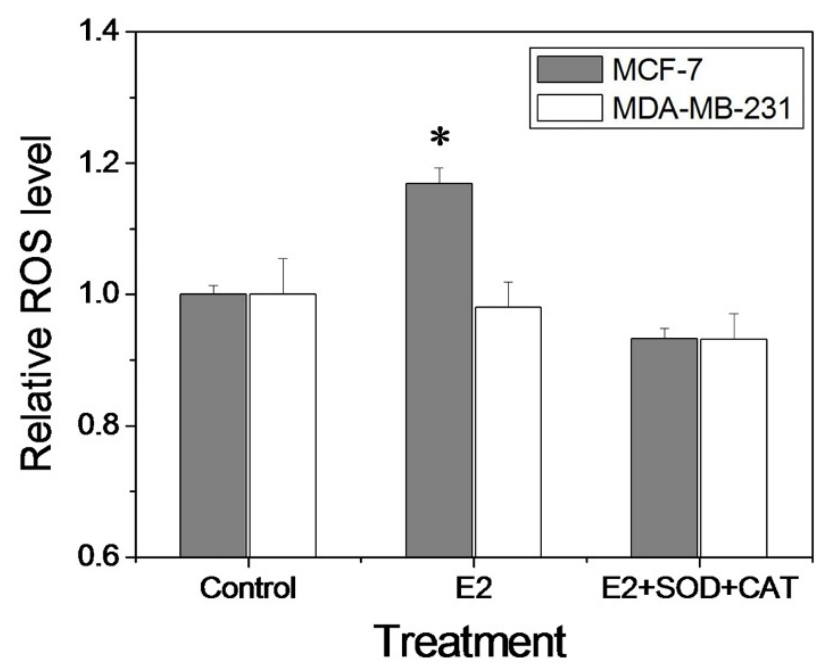

Figure 3

Relative ROS levels. MCF-7 cells and MDA-MB-23 I cells were treated with E2 or the mixture of E2 and SOD plus CAT (*, $P<0.0$ I compared to the control without E2 treatment). genotoxic activity of E2 is thought to be tightly linked to an oxidative element probably involving an ER-mediated mechanism. At physiological concentrations of E2, an ERmediated pathway is more capable of inducing increases in ROS through the regulation of antioxidant genes [43]. E2 can be preferentially oxidised by cytochrome P-450 to produce 2-hydroxyestradiol that reacts with DNA and can be further oxidized to quinone acocmpanied by generation of ROS [54].

Moreover, we find that the E2-induced ROS contribute to the E2-enhanced radiosensitivity and bystander response of MCF-7 cells (Fig. 4). However, ROS may not be the only signalling factor involved in the bystander response because they can be produced in both irradiated and nonirradiated cells after E2-treatment. We have recently found that nitric oxide (NO) can be produced in irradiated MCF7 cells. Even when only $1 \%$ of cells are targeted, the NO level in the whole cell population can be increased by $19 \%$ relative to controls (data not shown). One possibility is that ROS increases not only the E2-enhanced radiosensitivity of MCF-7 cells but also the cellular sensitivity to other toxic factors including $\mathrm{NO}$ and its downstream products induced by radiation so that the bystander response of cellular damage can be increased by the E2treatment. As E2 is an essential factor for the development and growth of breast cancer cells, our finding that E2 increases the radiation-induced bystander effect may have relevance for the future development of radiationdependent therapies for breast cancer.

Bystander responses have also been observed in breast tumour cells after various chemical treatments. For example, using a co-culture approach, Chhipa and Bhat reported increased bystander cell killing in MCF-7 cells co-culutred with MDA-MB-231 cells which had been pretreated with 5-fluorouracil (5-FU) and this was mediated by the Fas/FasL system [55]. In another study pre-treatment of breast cells with paclitaxel, leads to increased ROS levels and this could produce increased cell killing in non paclitaxel treated bystander cells [56]. 


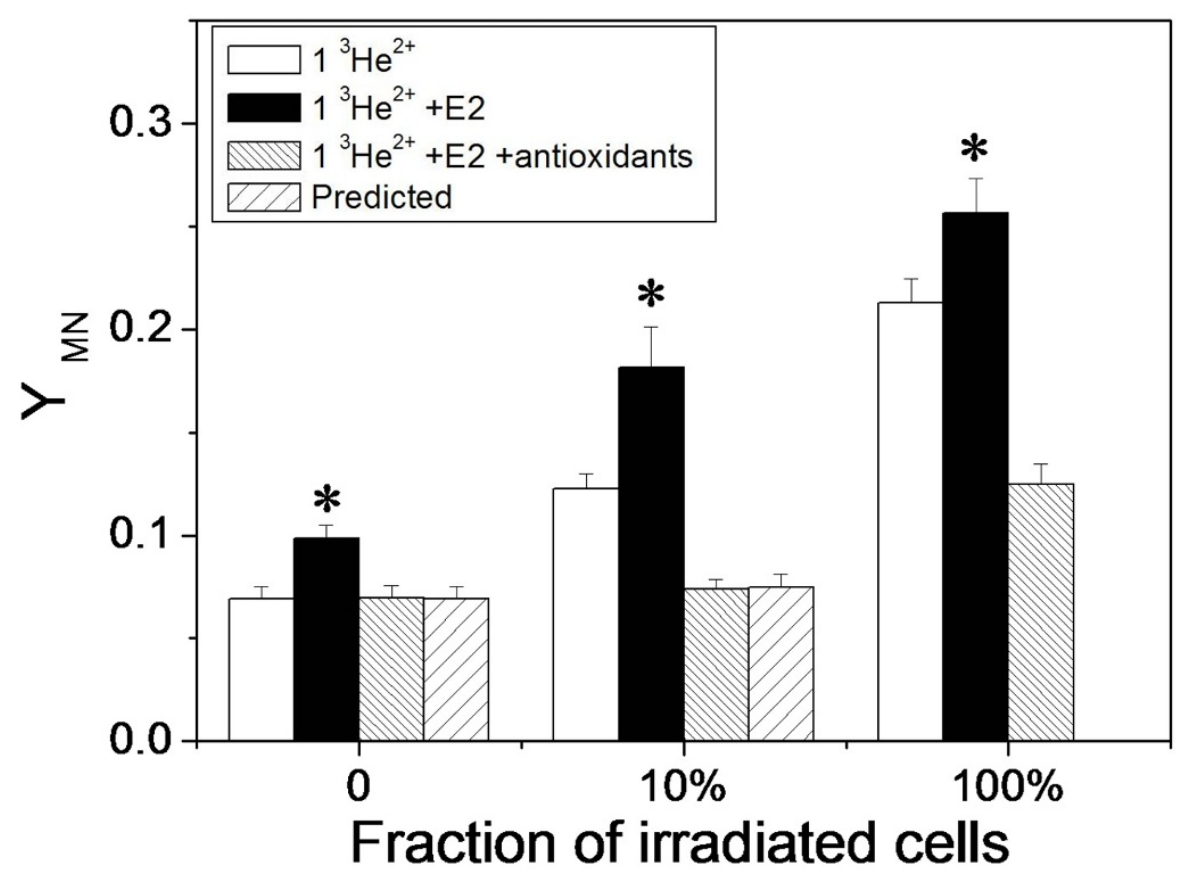

Figure 4

Influence of E2 and antioxidants on formation of radiation-induced MN in MCF-7 cells. A fraction of cells were individually irradiated with I ${ }^{3} \mathrm{He}^{2+}$ particle. The predicted yields of $\mathrm{MN}$ assuming no bystander effect were calculated from the yield of $M N$ when $100 \%$ of cells were irradiated with antioxidant treatment $(*, P<0.05$ compared to the MN yield of MCF-7 cells without E2 treatment).

\section{Conclusion}

We report here evidence for radiation-induced bystander responses in breast tumour cells. In MCF-7 cells, the bystander response could be enhanced by treatment with E2 and quenched by the addition of TAM in an ROS dependent manner, neither of which modulated the bystander response in MDA-MD-231 cells. The observation of bystander responses in breast tumour cells may offer new potential targets for radiation-based therapies in the future.

\section{Abbreviations}

ROS: reactive oxygen species; E2: $17 \beta$-estradiol; ER: Estrogen receptor; TAM: Tamoxifen, NO: nitric oxide; $\mathrm{MN}$ : micronucleus; $\mathrm{BN}$ : binucleate.

\section{Competing interests}

The authors declare that they have no competing interests.

\section{Authors' contributions}

CS performed experiments, MF designed microbeam study, KDH and KMP designed study, analysed data. CS wrote the manuscript and $\mathrm{KDH}$ and KMP revised manuscript.

\section{Acknowledgements}

We thank Stuart Gilchrist and Bob Sunderland for assistance with irradiations using the Gray Cancer Institute Charged Particle Microbeam. This work was supported by Cancer Research UK [CUK] grant number $\mathrm{Cl} 5 \mathrm{I} 3 /$ A7047, the Gray Cancer Institute, and partly by the Grant (No. 06PJ I40 I2) from the Science \& Technology Commission of Shanghai Municipality.

\section{References}

I. Prise KM, Schettino G, Folkard M, Held KD: New insights on cell death from radiation exposure. The lancet oncology 2005, 6(7):520-528.

2. Nagasawa $H$, Little JB: induction of sister chromatid exchanges by extremely low doses of a-particles. Cancer Research 1992, 52:6394-6396.

3. Azzam El, de Toledo SM, Little JB: Direct evidence for the participation of gap junction-mediated intercellular communication in the transmission of damage signals from alpha particle irradiated to nonirradiated cells. Proceedings of the National Academy of Sciences of the United States of America 200I, 98(2):473-478.

4. Lyng FM, Seymour CB, Mothersill C: Production of a signal by irradiated cells which leads to a response in unirradiated cells characteristic of initiation of apoptosis. British Journal of Cancer 2000, 83(9): I223-1230.

5. Mothersill C, Seymour C: Medium from irradiated human epithelial cells but not human fibroblasts reduces the clonogenic survival of irradiated cells. International Journal of Radiation Biology 1997, 7 I:421-427.

6. Shao C, Furusawa Y, Aoki M, Matsumoto H, Ando K: Nitric oxidemediated bystander effect induced by heavy-ions in human salivary gland tumour cells. International Journal of Radiation Biology 2002, 78(9):837-844.

7. Shao C, Furusawa Y, Kobayashi Y, Funayama T, Wada S: Bystander effect induced by counted high-LET particles in confluent 
human fibroblasts: a mechanistic study. FASEB Journal 2003 I 7(I I): I 422-I 427.

8. Zhou H, Randers-Pehrson G, Waldren CA, Vannais D, Hall EJ, Hei TK: Induction of a bystander mutagenic effect of alpha particles in mammalian cells. Proceedings of the National Academy of Sciences of the United States of America 2000, 97(5):2099-2 104.

9. Prise KM, Belyakov OV, Folkard M, Michael BD: Studies of bystander effects in human fibroblasts using a charged particle microbeam. International Journal of Radiation Biology 1998, 74:793-798.

10. Shao C, Folkard M, Michael BD, Prise KM: Targeted cytoplasmic irradiation induces bystander responses. Proceedings of the National Academy of Sciences of the United States of America 2004, I 0 I(37): I 3495- I 3500.

II. Yang H, Asaad N, Held KD: Medium-mediated intercellular communication is involved in bystander responses of $X$-rayirradiated normal human fibroblasts. Oncogene 2005 24:2096-103.

12. Burdak-Rothkamm S, Short SC, Folkard M, Rothkamm K, Prise KM: ATR-dependent radiation-induced gammaH2AX foci in bystander primary human astrocytes and glioma cells. Oncogene 2007, 26(7):993-1002

13. Mothersill C, Stamato TD, Perez ML, Cummins R, Mooney R, Seymour CB: Involvement of energy metabolism in the production of 'bystander effects' by radiation. Br J Cancer 2000 , 82(10): I740-I746.

14. Nagasawa H, Cremesti A, Kolesnick R, Fuks Z, Little JB: Involvement of membrane signaling in the bystander effect in irradiated cells. Cancer Research 2002, 62(9):253 I-2534.

15. Deshpande A, Goodwin EH, Bailey SM, Marrone BL, Lehnert BE: Alpha-particle-induced sister chromatid exchange in norma human lung fibroblasts: Evidence for an extranuclear target. Radiation Research 1996, 145:260-267.

16. Ponnaiya B, Jenkins-Baker G, Brenner DJ, Hall EJ, Randers-Pehrson G, Geard CR: Biological responses in known bystander cells relative to known microbeam-irradiated cells. Radiation Research 2004, 162(4):426-432.

17. Shao C, Folkard M, Michael BD, Prise KM: Bystander signaling between glioma cells and fibroblasts targeted with counted particles. Int J Cancer 2005, I I6(I):45-5 I.

18. Little JB: Radiation carcinogenesis. Carcinogenesis 2000, 2 I(3):397-404.

19. Zhou H, Suzuki M, Randers-Pehrson G, Vannais D, Chen G, Trosko JE, Waldren CA, Hei TK: Radiation risk to low fluences of alpha particles may be greater than we thought. Proceedings of the National Academy of Sciences of the United States of America 200I, 98(25): |44|0-I44|5.

20. Lorimore SA, Coates PJ, Wright EG: Radiation-induced genomic instability and bystander effects: inter-related nontargeted effects of exposure to ionizing radiation. Oncogene 2003 , 22(45):7058-7069.

21. Hall EJ, Hei TK: Genomic instability and bystander effects induced by high-LET radiation. Oncogene 2003 , 22(45): 7034-7042.

22. Lewis DA, Mayhugh BM, Qin Y, Trott K, Mendonca MS: Production of delayed death and neoplastic transformation in CGLI cells by radiation-induced bystander effects. Radiation Research 200I, I 56(3):25I-258

23. Sawant SG, Randers-Pehrson G, Geard CR, Brenner DJ, Hall EJ: The bystander effect in radiation oncogenesis: I. Transformation in $\mathrm{C} 3 \mathrm{H} \mathrm{IOTI/2}$ cells in vitro can be initiated in the unirradiated neighbors of irradiated cells. Radiation Research 200I, I 55(3):397-40I.

24. Azzam El, de Toledo SM, Gooding T, Little JB: Intercellular communication is involved in the bystander regulation of gene expression in human cells exposed to very low fluences of alpha particles. Radiat Res 1998, I 50(5):497-504.

25. Tartier L, Gilchrist S, Burdak-Rothkamm S, Folkard M, Prise KM: Cytoplasmic irradiation induces mitochondrial-dependent 53BPI protein relocalization in irradiated and bystander cells. Cancer Research 2007, 67( (12):5872-5879.

26. Shao C, Furusawa Y, Aoki M, Ando K: Role of gap junctional intercellular communication in radiation-induced bystander effects in human fibroblasts. Radiation Research 2003, 160(3):318-323
27. Azzam El, de Toledo SM, Little JB: Oxidative metabolism, gap junctions and the ionizing radiation-induced bystander effect. Oncogene 2003, 22(45):7050-7057.

28. Mitchell SA, Randers-Pehrson G, Brenner DJ, Hall EJ: The bystander response in $\mathrm{C} 3 \mathrm{H}$ IOTI/2 cells: the influence of cellto-cell contact. Radiation Research 2004, I 6 I(4):397-40 I.

29. lyer R, Lehnert BE: Factors underlying the cell growth-related bystander responses to alpha particles. Cancer Research 2000, 60(5): $1290-1298$

30. Lehnert BE, Goodwin EH: Extracellular factor(s) following exposure to a-particles can cause sister chromatid exchanges in normal human cells. Cancer Research 1997 , 57:2164-2I7I.

31. Narayanan PK, Goodwin EH, Lehnert BE: a-particles initiate biological production of superoxide anions and hydrogen peroxide in human cells. Cancer Research 1997, 57:3963-3971.

32. Shao C, Stewart V, Folkard M, Michael BD, Prise KM: Nitric oxidemediated signaling in the bystander response of individually targeted glioma cells. Cancer Research 2003, 63(23):8437-8442.

33. Matsumoto H, Hayashi S, Hatashita M, Ohnishi K, Shioura H, Ohtsubo $\mathrm{T}$, Kitai R, Ohnishi T, Kano E: Induction of radioresistance by a nitric oxide-mediated bystander effect. Radiation Research 200I, I55(3):387-396.

34. Brenner DJ, Doll R, Goodhead DT, Hall EJ, Land CE, Little JB, Lubin $J$ J, Preston DL, Preston RJ, Puskin JS, Ron E, Sachs RK, Samet JM, Setlow RB, Zaider M: Cancer risks attributable to low doses of ionizing radiation: assessing what we really know. Proceedings of the National Academy of Sciences of the United States of America 2003, I00(24): $1376 \mid-13766$

35. Schmidberger H, Hermann RM, Hess CF, Emons G: Interactions between radiation and endocrine therapy in breast cancer. Endocrine-related cancer 2003, 10(3):375-388.

36. Razandi M, Pedram A, Levin ER: Plasma membrane estrogen receptors signal to antiapoptosis in breast cancer. Molecular endocrinology (Baltimore, Md 2000, I4(9): I434- I447.

37. Wazer DE, Tercilla OF, Lin PS, Schmidt-Ullrich R: Modulation in the radiosensitivity of MCF-7 human breast carcinoma cells by I7B-estradiol and tamoxifen. The British journal of radiology 1989, 62(744): 1079-1083.

38. Villalobos M, Becerra D, Nunez MI, Valenzuela MT, Siles E, Olea N, Pedraza $V$, Ruiz de Almodovar JM: Radiosensitivity of human breast cancer cell lines of different hormonal responsiveness. Modulatory effects of oestradiol. International Journal of Radiation Biology 1996, 70(2): 161-169.

39. Amorino GP, Freeman ML, Choy $\mathrm{H}$ : Enhancement of radiation effects in vitro by the estrogen metabolite 2-methoxyestradiol. Radiat Res 2000, I53(4):384-391.

40. Sarkaria JN, Miller EM, Parker C], Jordan VC, Mulcahy RT: 4-Hydroxytamoxifen, an active metabolite of tamoxifen, does not alter the radiation sensitivity of MCF-7 breast carcinoma cells irradiated in vitro. Breast cancer research and treatment 1994 , 30(2): $159-165$

4I. Paulsen GH, Strickert T, Marthinsen AB, Lundgren S: Changes in radiation sensitivity and steroid receptor content induced by hormonal agents and ionizing radiation in breast cancer cells in vitro. Acta oncologica (Stockholm, Sweden) 1996, 35(8): I0II-1019.

42. Folkard M, Vojnovic B, Prise KM, Bowey AG, Locke RJ, Schettino G, Michael BD: A charged-particle microbeam I. Development of an experimental system for targeting cells individually with counted particles. Int J Radiat Biol 1997, 72:375-385.

43. Mobley JA, Brueggemeier RW: Estrogen receptor-mediated regulation of oxidative stress and DNA damage in breast cancer. Carcinogenesis 2004, 25(I):3-9.

44. Folkard M, Voinovic B, Hollis KJ, Bowey AG, Watts SJ, Schettino G, Prise KM, Michael BD: A charged particle microbeam: II A single-particle micro-collimation and detection system. International Journal of Radiation Biology 1997, 72:387-395.

45. Albertini RJ, Anderson D, Douglas GR, Hagmar L, Hemminki K, Merlo F, Natarajan AT, Norppa H, Shuker DE, Tice R, Waters MD, Aitio A: IPCS guidelines for the monitoring of genotoxic effects of carcinogens in humans. International Programme on Chemical Safety. Mutation research 2000, 463(2): I I I-I72.

46. Arnold SF, Tims E, Bluman EM, McGrath BE: Regulation of transforming growth factor betal by radiation in cells of two human breast cancer cell lines. Radiat Res 1999, I52(5):487-492. 
47. Valerie K, Yacoub A, Hagan MP, Curiel DT, Fisher PB, Grant S, Dent $P$ : Radiation-induced cell signaling: inside-out and outside-in. Molecular cancer therapeutics 2007, 6(3):789-80I.

48. Shao C, Folkard M, Prise KM: Role of TGF-beta I and nitric oxide in the bystander response of irradiated glioma cells. Oncogene 2008, 27(4):434-440.

49. Shao C, Prise KM, Folkard M: Signaling factors for irradiated glioma cells induced bystander responses in fibroblasts. Mutat Res 2008, 638(I-2): |39-145.

50. Liehr JG: Is estradiol a genotoxic mutagenic carcinogen? Endocrine reviews 2000, 21 (I):40-54.

5I. Fischer WH, Keiwan A, Schmitt E, Stopper H: Increased formation of micronuclei after hormonal stimulation of cell proliferation in human breast cancer cells. Mutagenesis 200I, I6(3):209-2I 2.

52. Stopper H, Schmitt E, Gregor C, Mueller SO, Fischer WH: Increased cell proliferation is associated with genomic instability: elevated micronuclei frequencies in estradiol-treated human ovarian cancer cells. Mutagenesis 2003, 18(3):243-247.

53. Han X, Liehr JG: 8-Hydroxylation of guanine bases in kidney and liver DNA of hamsters treated with estradiol: role of free radicals in estrogen-induced carcinogenesis. Cancer Res 1994, 54(2I):55I5-55I7.

54. Hurh YJ, Chen ZH, Na HK, Han SY, Surh YJ: 2-Hydroxyestradiol induces oxidative DNA damage and apoptosis in human mammary epithelial cells. J Toxicol Environ Health A 2004, 67(2324): 1939-1953.

55. Chhipa RR, Bhat MK: Bystander killing of breast cancer MCF-7 cells by MDA-MB-23 I cells exposed to 5 -fluorouracil is mediated via Fas. Journal of cellular biochemistry 2007, I0I(I):68-79.

56. Alexandre J, Hu Y, Lu W, Pelicano H, Huang P: Novel action of paclitaxel against cancer cells: bystander effect mediated by reactive oxygen species. Cancer Research 2007, 67(8):35I2-35I7.

\section{Pre-publication history}

The pre-publication history for this paper can be accessed here:

http://www.biomedcentral.com/1471-2407/8/184/pre pub

Publish with Bio Med Central and every scientist can read your work free of charge

"BioMed Central will be the most significant development for disseminating the results of biomedical research in our lifetime. "

Sir Paul Nurse, Cancer Research UK

Your research papers will be:

- available free of charge to the entire biomedical community

- peer reviewed and published immediately upon acceptance

- cited in PubMed and archived on PubMed Central

- yours - you keep the copyright 